\title{
FLEXURAL BEHAVIOR OF STRUCTURAL LIGHTWEIGHT CONCRETE BEAMS
}

\author{
Louay A. Aboul-Nour
}

Associate Professor of Concrete Structures, Department of Civil Engineering, Faculty of Engineering, Zagazig University, Zagazig, Egypt.

\section{Mahmoud Yahia Attia Zaghlal}

Lecturer of Concrete Structures, Department of Civil Engineering, Faculty of Engineering, Zagazig University, Zagazig, Egypt.

\section{Khaled Adly Malek}

Demonstrator, Department of Civil Engineering, Faculty of Engineering, Sinai University, North-Sinai, Egypt.

\begin{abstract}
Compressive strength is the most effective mechanical property to produce structural lightweight aggregate concrete, by increasing compressive strength the other mechanical properties such as tensile strength, modulus of elasticity, and flexural strength also increase, it was indicated that the type of lightweight concrete, and the type of lightweight aggregate are the most effective factors on the value of compressive strength, so that structural lightweight aggregate concrete was produced using expanded polystyrene having size less than $4.75 \mathrm{~mm}$ as $60 \%$ replacement ratio of normal weight fine aggregate (sand)by, cement content $360 \mathrm{Kg} / \mathrm{m} 3,90 \mathrm{Kg} / \mathrm{m} 3$ silica fume was added with $20 \%$ replacement ratio of cement by weight, and high range water reducer was used with $2 \%$ of cement by weight, and $45 \%$ water to cement ratio was used, the experimental work was to determine the compressive strength, tensile strength, and flexural strength of that mix, reinforced concrete beams made from the previous mix were cast and compared with reinforced normal weight concrete beams, lightweight aggregate beams were cast with different shear span to depth ratios (a/d), different reinforcement steel to concrete ratio $(\mu)$, different shear reinforcement, different cases of loading, once three points of loading, another time four points of loading, the load deflection curve of concrete was drawn using LVDT, and strain gauges were put on the surface of bottom steel bar in order to measure strain in it subsequently draw load-strain curve for steel.
\end{abstract}

Key words: Structural Lightweight Aggregate Concrete, Expanded Polystyrene, Flexural Behavior of Lightweight Concrete Beams. 
Cite this Article: Louay A. Aboul-Nour, Mahmoud Yahia Attia Zaghlal and Khaled Adly Malek, Flexural Behavior of Structural Lightweight Concrete Beams. International Journal of Civil Engineering and Technology (IJCIET), 11(1), 2020, pp.329-339

https://iaeme.com/Home/issue/IJCIET?Volume=11\&Issue=1

\section{INTRODUCTION}

Mechanical properties of Lightweight concrete is less than that for normal weight concrete, using light weight aggregate instead of normal weight aggregate caused a slight reduction in strength of light weight concrete [1], compressive strength is regarded as indicator on the other mechanical properties of Lightweight concrete such as tensile strength, and flexural strength, so that the factors affecting on compressive strength should be studied especially the type of lightweight concrete and type of used lightweight aggregate, Expanded polystyrene particle size and the granules content controls the mechanical properties of Expanded polystyrene concrete [2], compressive strength of light weight expanded polystyrene concrete are negatively affected by increasing the volume of expanded polystyrene in the mix [3], Smaller expanded polystyrene aggregate gives higher compressive strength for expanded polystyrene aggregate concrete, increase in compressive strength is more evident in low density concrete more than high density concrete, bigger size and higher volume of expanded polystyrene aggregate causes higher moisture migration and absorption [4]), "EPS dosage has the most significant effect on compressive strength of EPS lightweight aggregate concrete, then water and cement ratio, while the content of cement and sand ratio play a comparatively less important part. The relationship between density and compressive strength of EPS lightweight aggregate concrete is proposed as $\mathrm{fc}=2.43 \times \gamma 2.997 \times 10^{-9 "}[5]$, lightweight aggregate concrete strength is inversely proportional to the water/cement ratio [6), the compressive strength of the light weight concrete increases by decreasing the inclusion size [7], The effect of particle size in EPS concrete on compressive strength is more effectual in low porosity concretes and could be neglected in very high porosity concretes [8], higher dry density and longer curing age of expanded polystyrene concrete increases compressive strength [9]. The concrete compressive strength controls coordinates of the key points used for drawing stressstrain curve, the entire curve shape can be predicted according to compressive strength [10], the compressive strength and elastic modulus of concrete are mainly affected by lightweight aggregates properties and the water to binder ratio [11], using polystyrene granules as replacement of aggregates caused reduction in density and mechanical properties of light weight concrete such as compressive strength [12], compressive strength and modulus of elasticity of lightweight aggregate concrete is directly proportional to the particle density, and the possibility of brittle failure occurring increases with increasing the volume content of light weight aggregate [13] larger volume fraction of expanded polystyrene aggregate causes reduction apparent density, tensile strength, compressive strength, elasticity modulus, and fracture toughness [14], splitting tensile strength controls the shear strength of structural lightweight aggregate concrete slabs rather than compressive strength [15], more Brittle failure occurs when the volume content of lightweight aggregate increases, for concretes with the same strength and light weight aggregate concrete is more brittle than normal weight concrete [16], by the time producing structural LWAC it may be used for a lot of purposes, "These lightweight panels produced using Expanded Polystyrene as 50\% of the total EPS used in a composite foam concrete can allow rapid construction while reducing the overall weight of the building, these walls can also be used as partition walls of multi storey buildings, it also has a flexural strength comparable with other masonry materials, The EPS based walls can be used as load bearing walls of single storey construction" [17]. 


\section{MATERIALS AND EXPERIMENTAL PROCEDURES}

\subsection{Materials}

Materials used to produce reinforced lightweight and normal weight concrete beams are shown in Tale (1) and properties of reinforcement steel are shown in Table (2)

Table 1 Properties of lightweight aggregate concrete raw materials

\begin{tabular}{|l|l|l|l|l|l|l|}
\hline Property & Crushed Dolomite & Sand & EP & Cement & SF & HRWR \\
\hline Specific Gravity & 2.67 & 2.53 & 3.15 & 3.15 & 2.15 & 1.15 \\
\hline Unit weight $(\mathrm{Kg} / \mathrm{m} 3)$ & 1770 & 1774 & 17 & & & \\
\hline Absorption ratio $(\%)$ & 1.5 & 5.2 & .8 & & & \\
\hline
\end{tabular}

Table 2 Properties of reinforcement steel

\begin{tabular}{|l|l|l|l|l|l|}
\hline $\begin{array}{l}\text { Diameter of steel } \\
\text { Bar }(\mathrm{mm})\end{array}$ & $\begin{array}{l}\text { Elastic } \\
\text { Modulus Es } \\
(\mathrm{GPa})\end{array}$ & $\begin{array}{l}\text { Yield } \\
\text { stress } \\
\text { fy }(\mathrm{MPa})\end{array}$ & $\begin{array}{l}\text { Yield } \\
\text { strain } \\
\mathrm{\varepsilon y}\end{array}$ & $\begin{array}{l}\text { Ultimate stress } \\
\text { fu (MPa) }\end{array}$ & $\begin{array}{l}\text { \% Elongation } \\
\text { at failure }\end{array}$ \\
\hline 12 & 203 & 540 & 0.0027 & 670 & $14.5 \%$ \\
\hline
\end{tabular}

\subsection{EXPERIMENTAL METHOD}

Reinforced concrete beams were cast to study the factors affecting on flexural behavior of beams as following,

- 3 lightweight expanded polystyrene concrete beams with constant (a/d) ratio equals to 5,4 loading points, and $2 \%, 1 \%$, and $1.5 \%$ steel to concrete ratios $\mu$ for beams $\mathrm{B} 1, \mathrm{~B} 2$, and B3 respectively to study the effect of steel to concrete ratio $\mu$ on flexural behavior of beams,

- 1 lightweight expanded polystyrene concrete beam B4 was cast with the same properties of B3 but it was subjected to 3 loading points, the results of structural behavior of that beam will be determined and compared with that for B3, to determine the effect of cases of loading beams on flexural behavior of beams,

- 2 lightweight expanded polystyrene concrete beams were cast with the same properties of B3 but with different (a/d) ratios equals to 3.6 and 1 for beams B5 and B6 respectively to study the effect of $(\mathrm{a} / \mathrm{d})$ ratio on the flexural behavior of beams

- 2 normal weight concrete beams, B7 and B8 with the same properties of B5 and B6 respectively to study the effect of concrete type on the flexural behavior of beams

Beams designation is shown in table 3 and concrete mix design and properties are shown in table 4, and reinforcement details of all concrete beams is shown from figure 1 to figure 5 . 
Table 3 Designation of Beams

\begin{tabular}{|c|c|c|c|c|c|}
\hline $\begin{array}{c}\text { Beam } \\
\text { Id }\end{array}$ & $\begin{array}{c}\text { Steel to } \\
\text { Concrete Ratio } \\
\mu \%\end{array}$ & $\begin{array}{c}\text { Shear Span to } \\
\text { Depth Ratio (a/d) }\end{array}$ & $\begin{array}{c}\text { Number of } \\
\text { Loading } \\
\text { Points }\end{array}$ & $\begin{array}{c}\text { Main Steel } \\
\text { Reinforcement }\end{array}$ & $\begin{array}{c}\text { Main Steel } \\
\text { Reinforcement }\end{array}$ \\
\hline B1 & 2 & 5 & 4 & $4 \emptyset 12$ & $7 \emptyset 8$ \\
\hline B2 & 1 & 5 & 4 & $2 \emptyset 12$ & $7 \emptyset 8$ \\
\hline B3 & 1.5 & 5 & 4 & $3 \emptyset 12$ & $7 \emptyset 8$ \\
\hline B4 & 1.5 & 5 & 3 & $3 \emptyset 12$ & $7 \emptyset 8$ \\
\hline B5 & 1.5 & 3.6 & 4 & $3 \emptyset 12$ & $7 \emptyset 8$ \\
\hline B6 & 1.5 & 3.6 & 4 & $3 \emptyset 12$ & $7 \emptyset 8$ \\
\hline B7 & 1.5 & 1 & 4 & $3 \emptyset 12$ & $7 \varnothing 8$ \\
\hline B8 & 1.5 & 1 & 4 & $3 \emptyset 12$ & $7 \emptyset 8$ \\
\hline
\end{tabular}

Table 4 Designation of Beams

\begin{tabular}{|c|c|c|c|c|c|c|c|c|}
\hline $\begin{array}{c}\text { Mix } \\
\text { Type }\end{array}$ & $\begin{array}{c}\text { Cement } \\
\text { Content } \\
\left(\mathrm{Kg} / \mathrm{m}^{3}\right)\end{array}$ & $\begin{array}{c}\text { Silica } \\
\text { Fume } \\
\text { Content } \\
\left(\mathrm{Kg} / \mathrm{m}^{3}\right)\end{array}$ & $\begin{array}{c}\text { Water } \\
\text { Content } \\
(\mathrm{Kg} / \mathrm{m} 3)\end{array}$ & $\begin{array}{c}\text { HRWR } \\
\text { Content } \\
\left(\mathrm{Kg} / \mathrm{m}^{3}\right)\end{array}$ & $\begin{array}{c}\text { Weight of } \\
\text { Sand } \\
\left(\mathrm{Kg} / \mathrm{m}^{3}\right)\end{array}$ & $\begin{array}{c}\text { Weight of } \\
\text { Crushed } \\
\text { Dolomite } \\
\left(\mathrm{Kg} / \mathrm{m}^{3}\right)\end{array}$ & $\begin{array}{c}\text { Weight of } \\
\text { LWA } \\
\left(\mathrm{Kg} / \mathrm{m}^{3}\right)\end{array}$ & $\begin{array}{c}\text { Compressive } \\
\text { Strength } \\
\left(\mathrm{Kg} / \mathrm{cm}^{2}\right)\end{array}$ \\
\hline NWC & 350 & 0 & 158 & 0 & 740 & 1163 & 0 & 253 \\
\hline LWC & 360 & 90 & 180 & 9 & 267 & 1049 & 2 & 194 \\
\hline
\end{tabular}

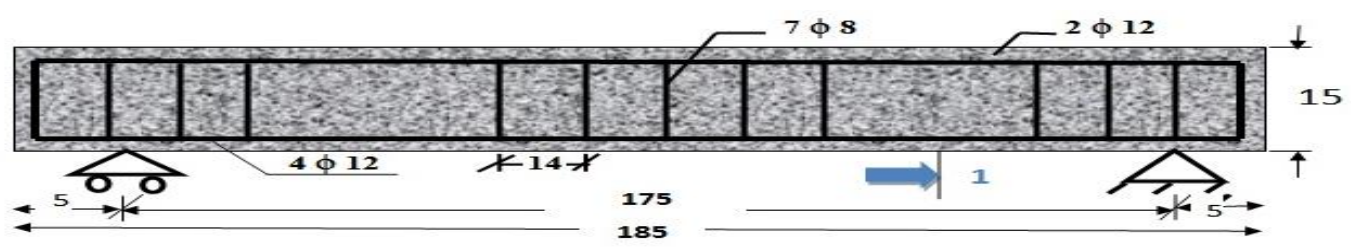

Figure 1 Reinforcement details of B1

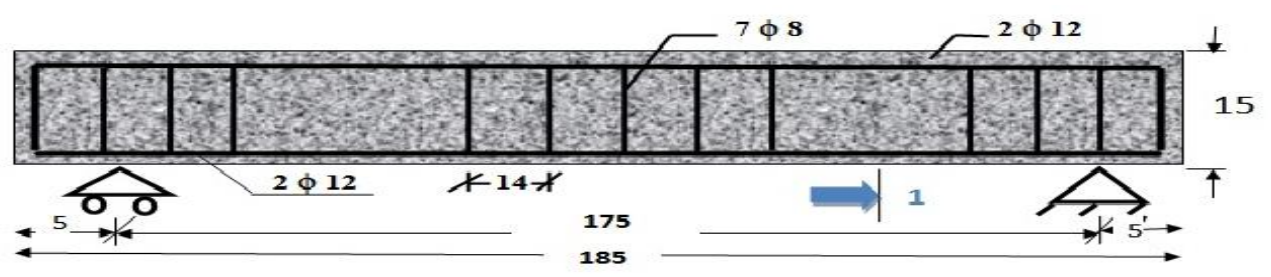

Figure 2 Reinforcement details of B2

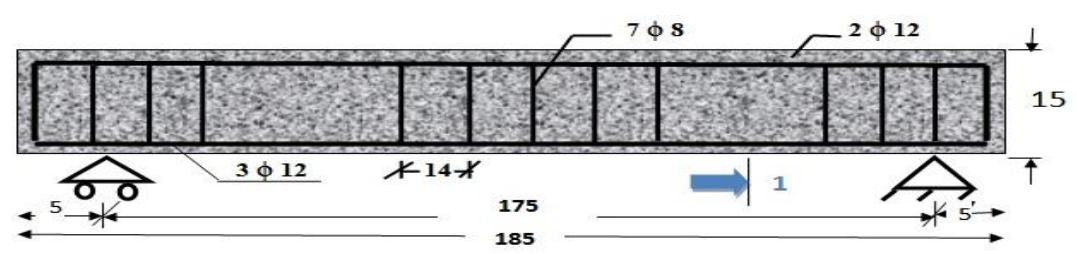

Figure 3 Reinforcement details of B3 and B4 


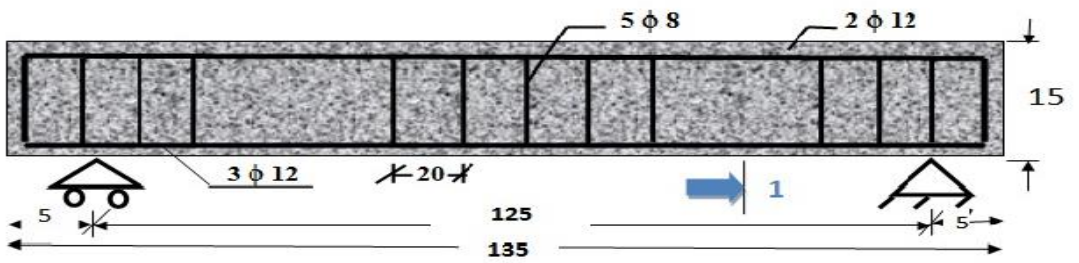

Figure 4 Reinforcement details of B5 and B7

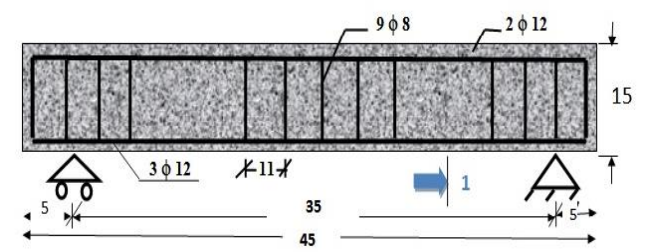

Figure 5 Reinforcement details of B6 and B8

Loading details on beams are shown from figure 6 to figure 9

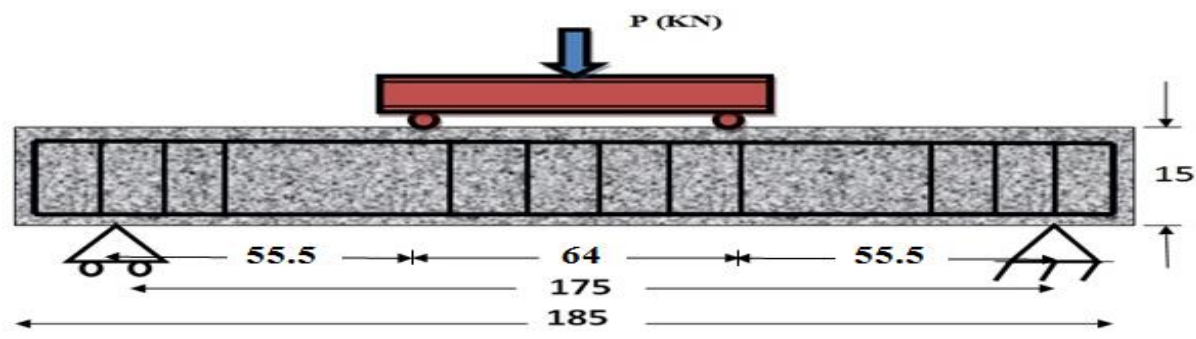

Figure 6 Reinforcement details of B2

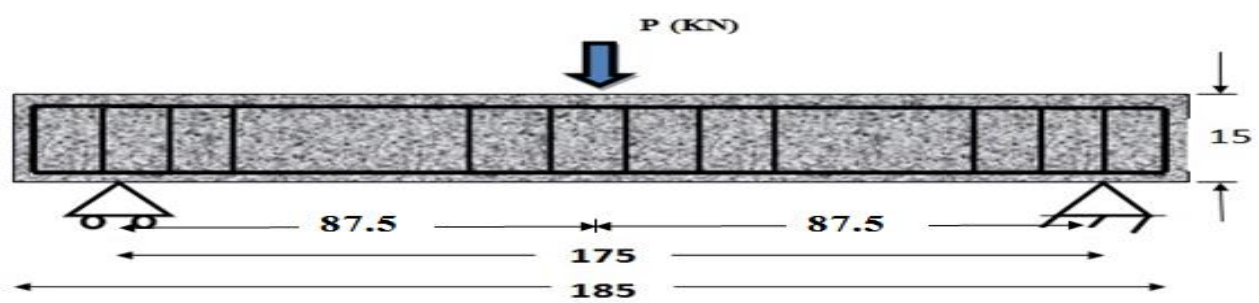

Figure 7 Loading on beams with $(\mathrm{a} / \mathrm{d}=4)$ and 4 points of loading

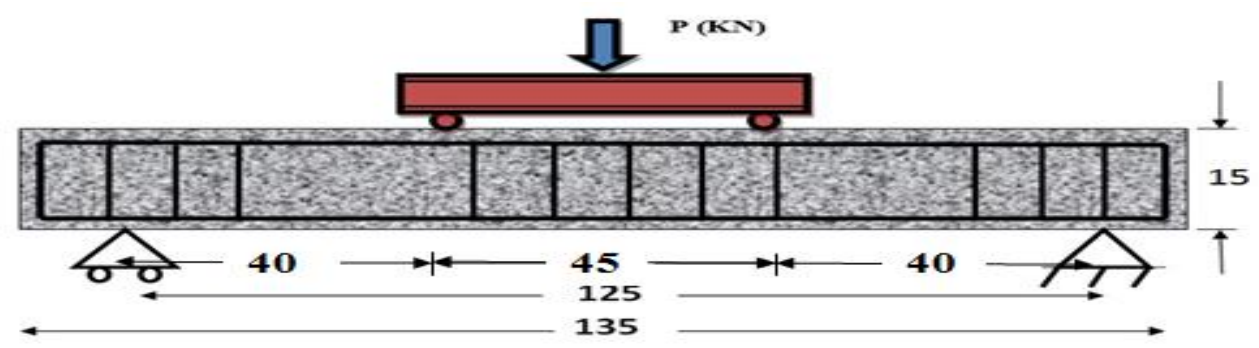

Figure 8 Loading on beams with $(\mathrm{a} / \mathrm{d}=3.6)$ and 4 points of loading 


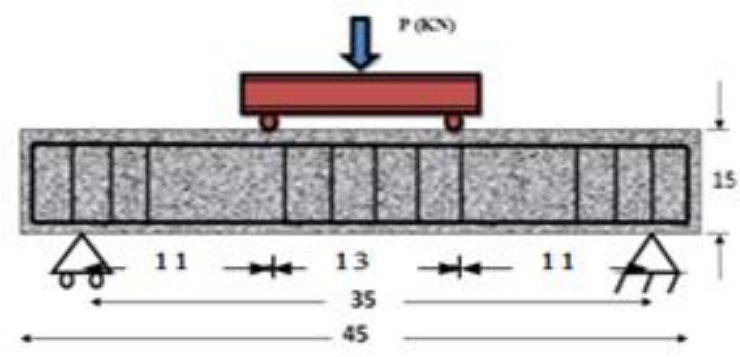

Figure 9 Loading on beams with $(\mathrm{a} / \mathrm{d}=1)$ and 4 points of loading

\section{ANALYSIS AND DISCUSSION}

\subsection{Flexural Strength of Concrete Beams}

The results of flexural strength test flexural behavior of reinforced lightweight fine aggregate concrete and normal weight concrete beams crack paterns for beams are shown from figure 10 to figure 17 .

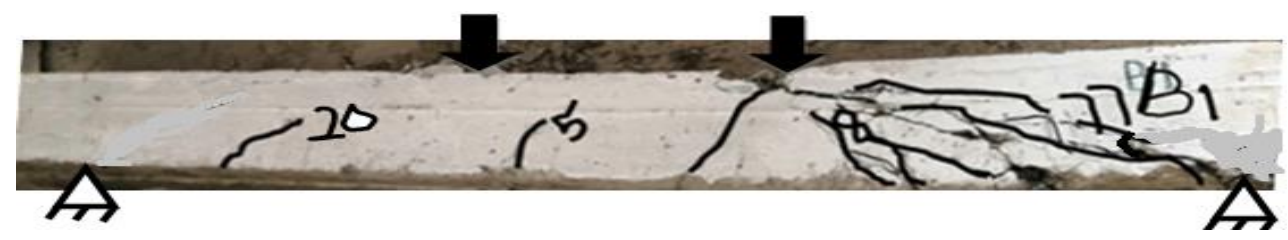

Figure 10 Crack pattern for beam B1

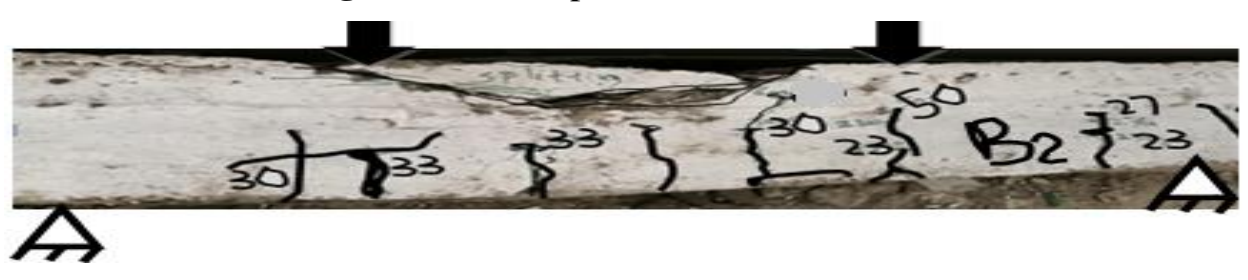

Figure 11 Crack pattern for beam B2

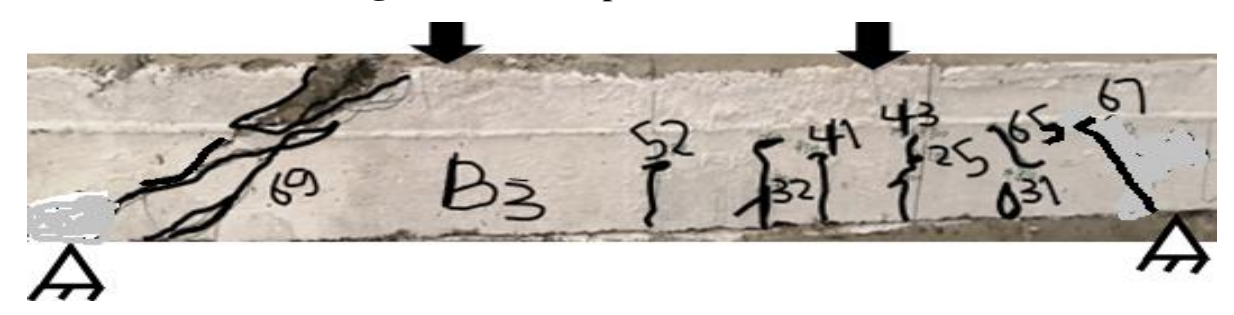

Figure 12 Crack pattern for beam B3

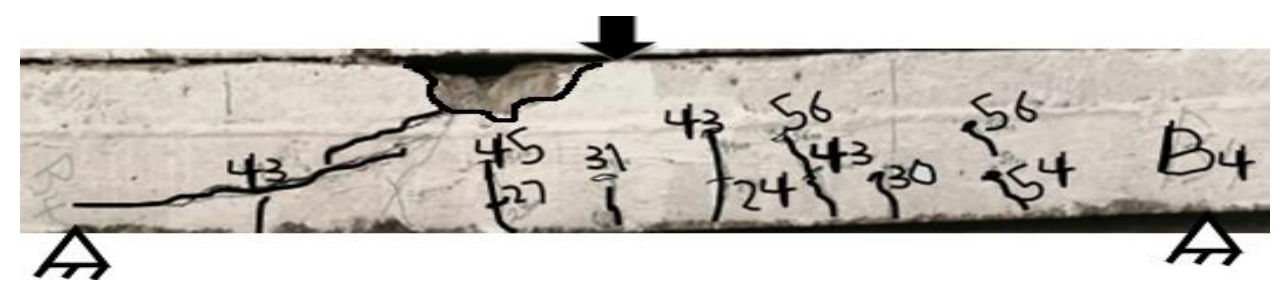

Figure 13 Crack pattern for beam B4 


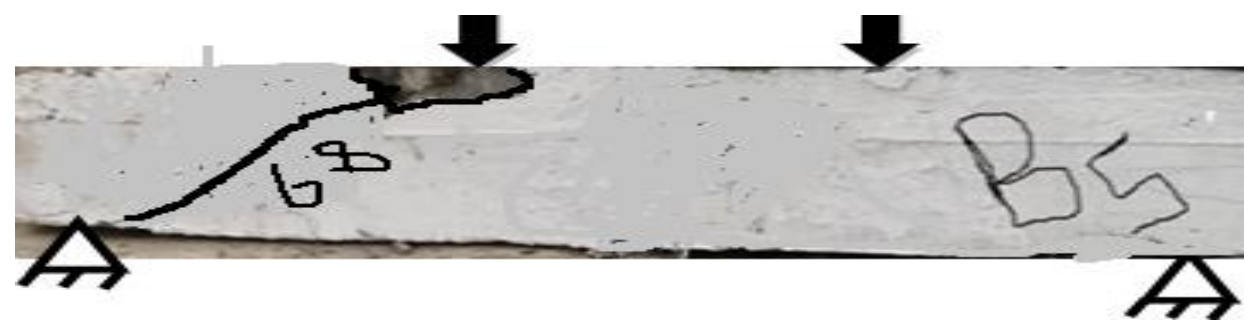

Figure 14 Crack pattern for beam B5

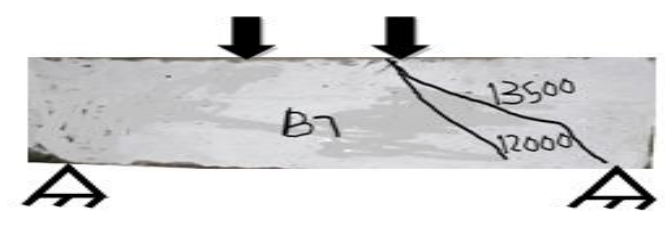

Figure 15 Crack pattern for beam B6

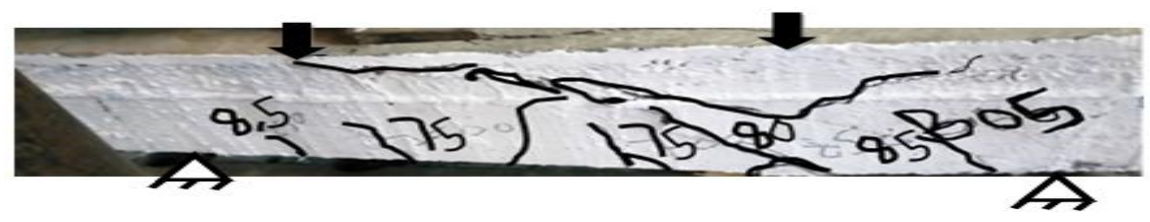

Figure 16 Crack pattern for beam Bo5

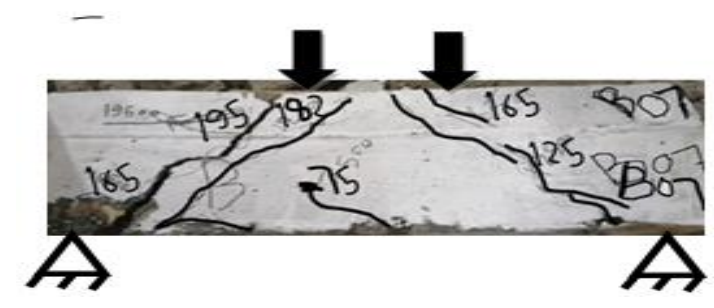

Figure 17 Crack pattern for beam Bo7

Load-deflection curve for concrete and Load_ strain curve for steel for beams are shown from figure 18 to figure 33

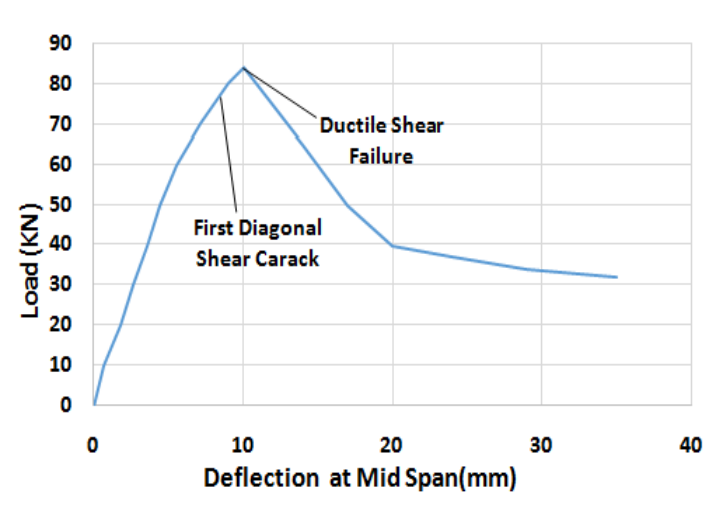

Figure 18 Load-deflection curve for beam B1

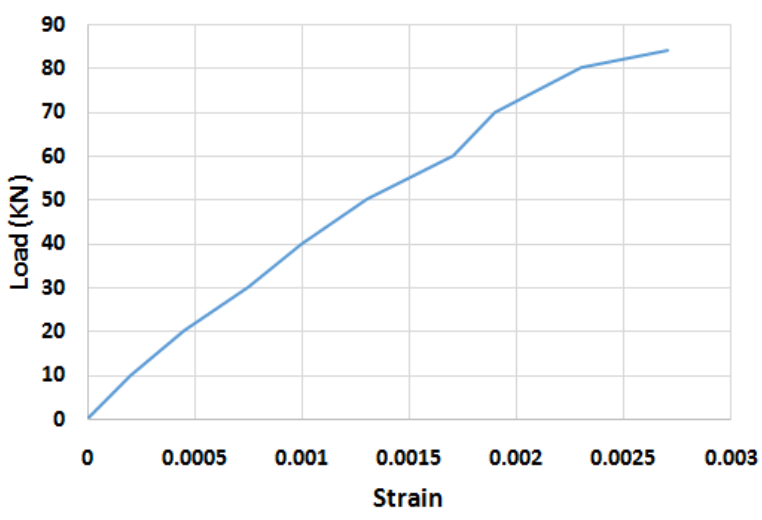

Figure 19 Load_strain of steel of B1 


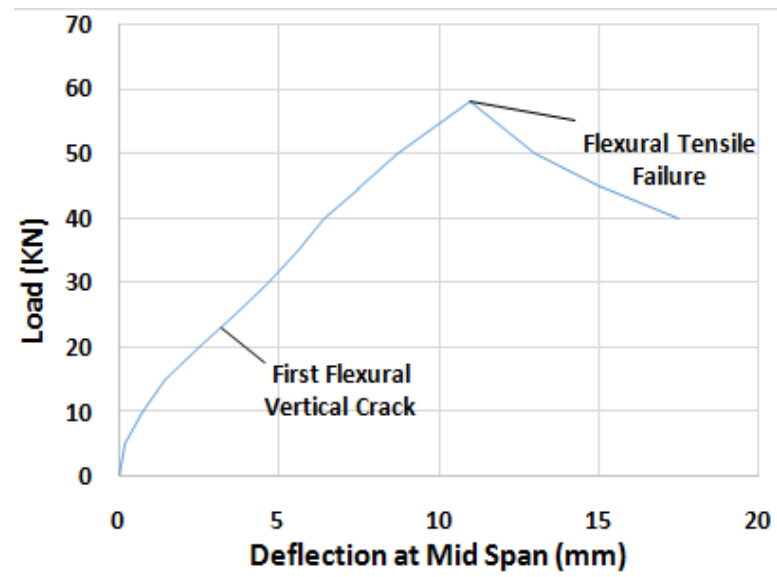

Figure 20 Load-deflection curve for Beam B2

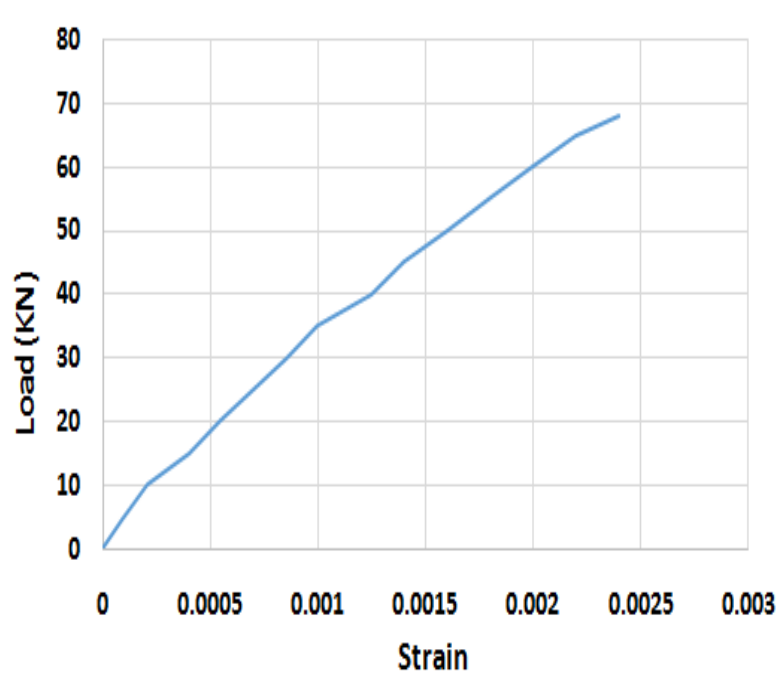

Figure 22 Load-deflection curve for Beam B3

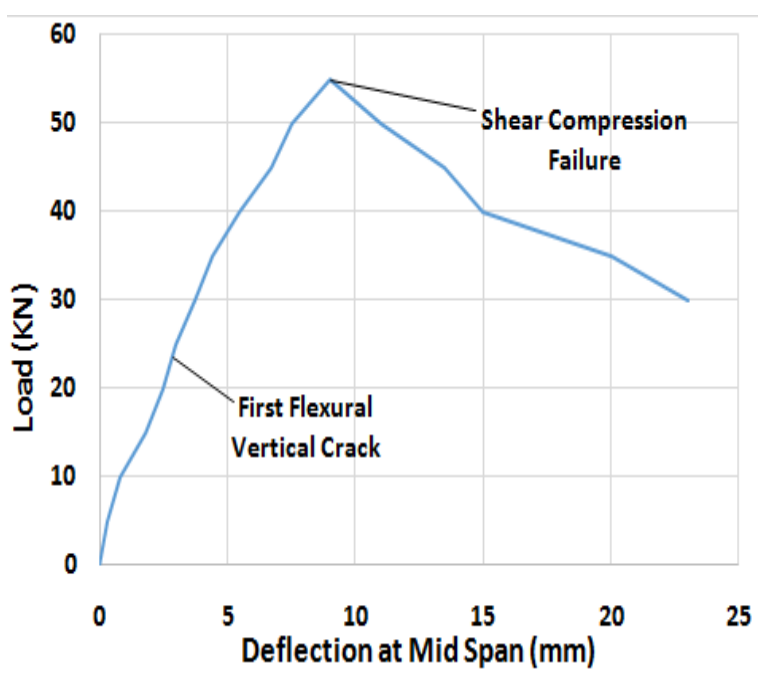

Figure 24 Load-deflection curve for beam B4

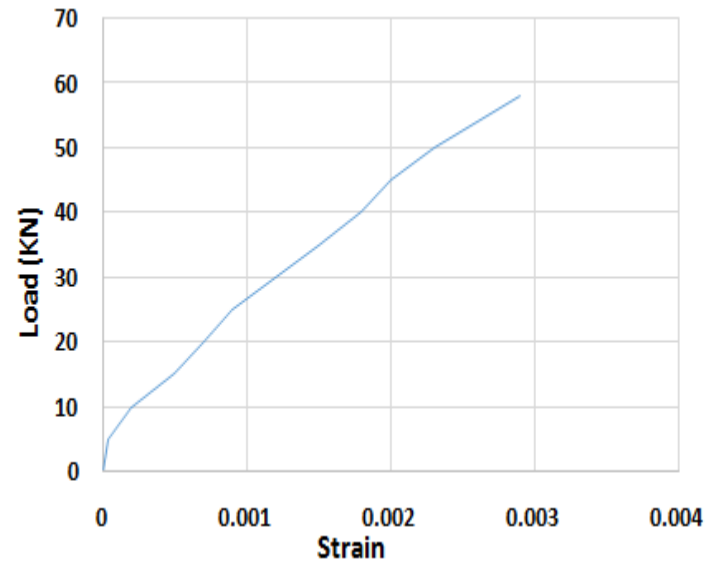

Figure 21 Load_strain of steel of B2

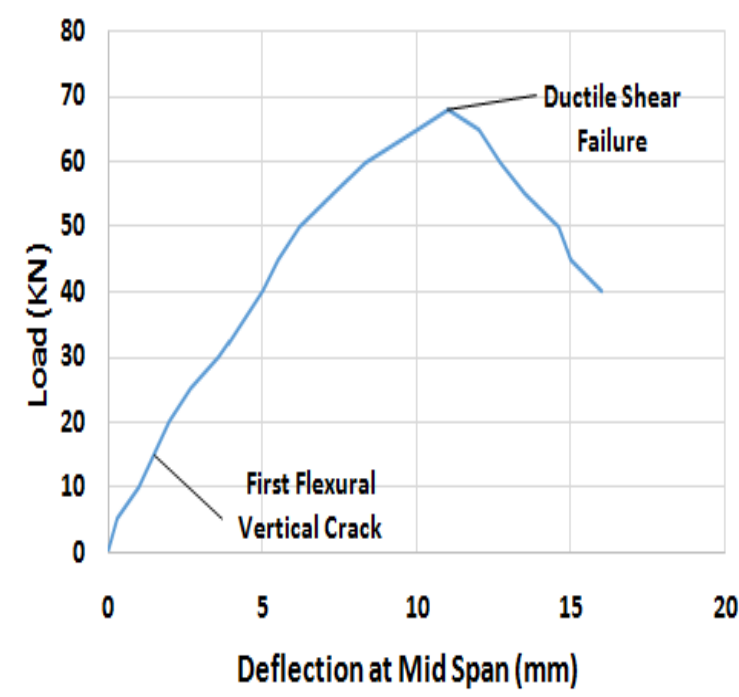

Figure 23 Load_strain of steel of B3

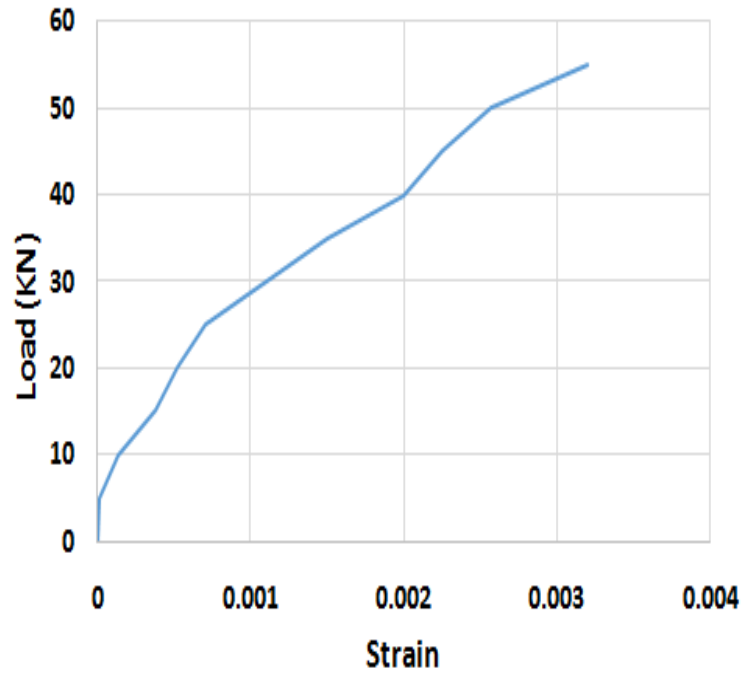

Figure 25 Load_strain of steel of B4 


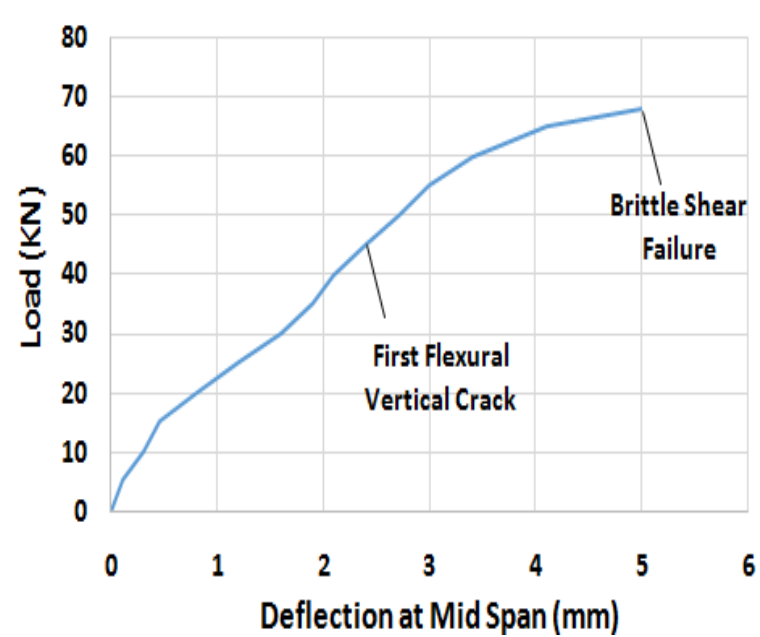

Figure 26 Load-deflection curve for beam B5

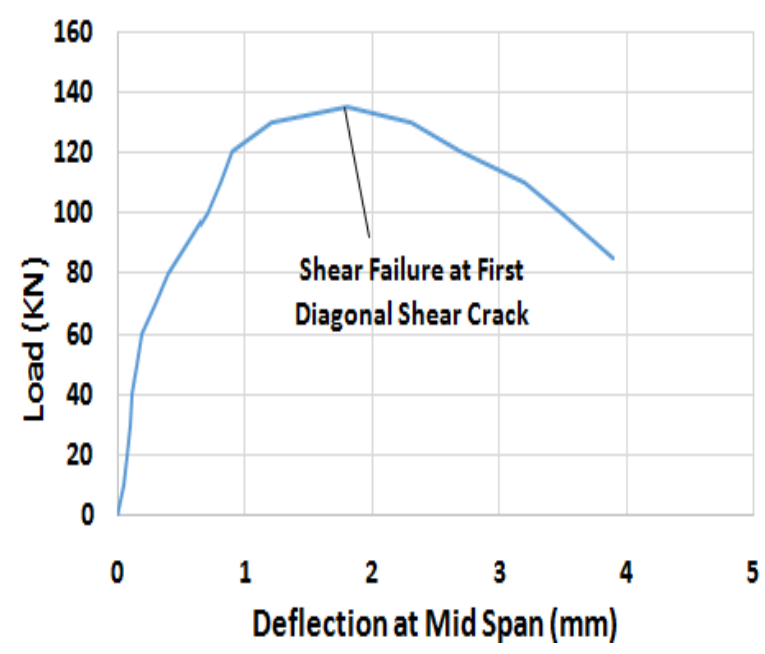

Figure 28 Load-deflection curve for beam B6

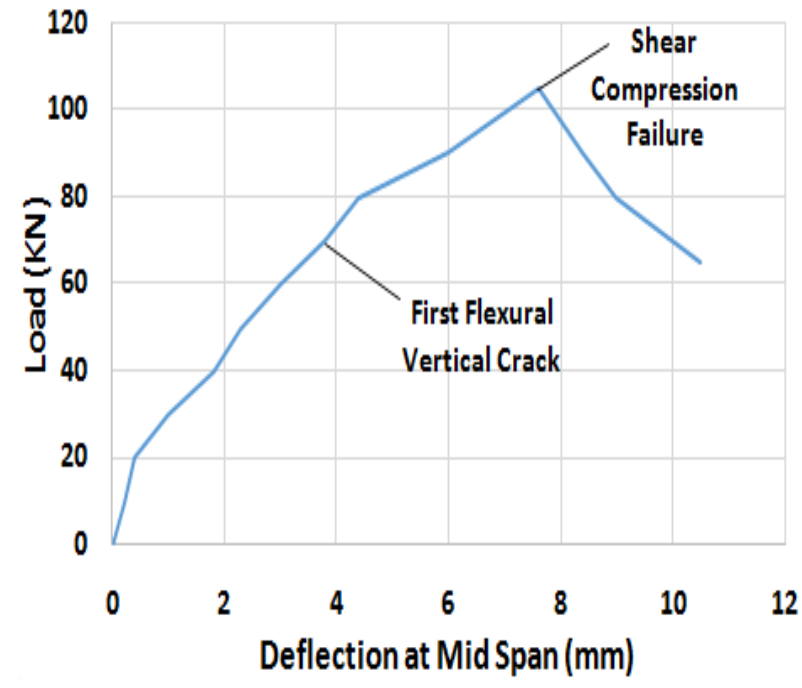

Figure 30 Load-deflection curve for beam B7

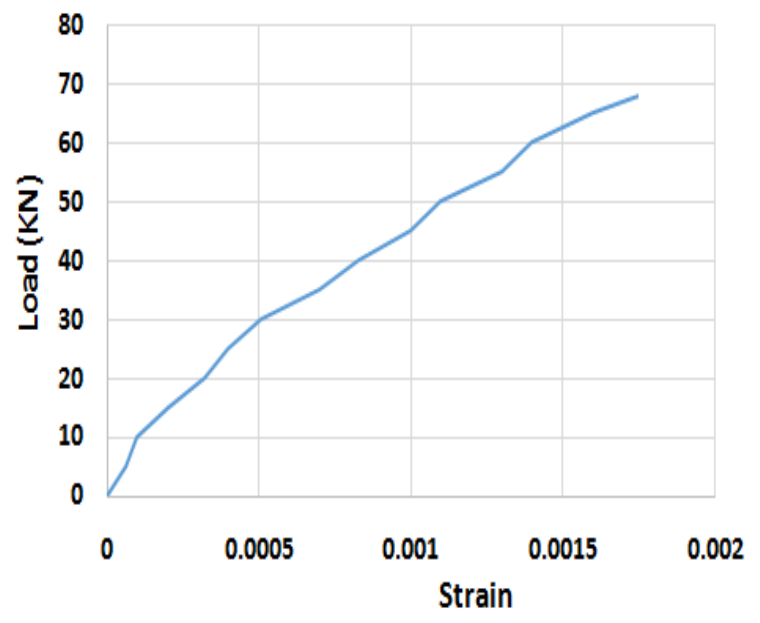

Figure 27 Load_strain of steel of B5

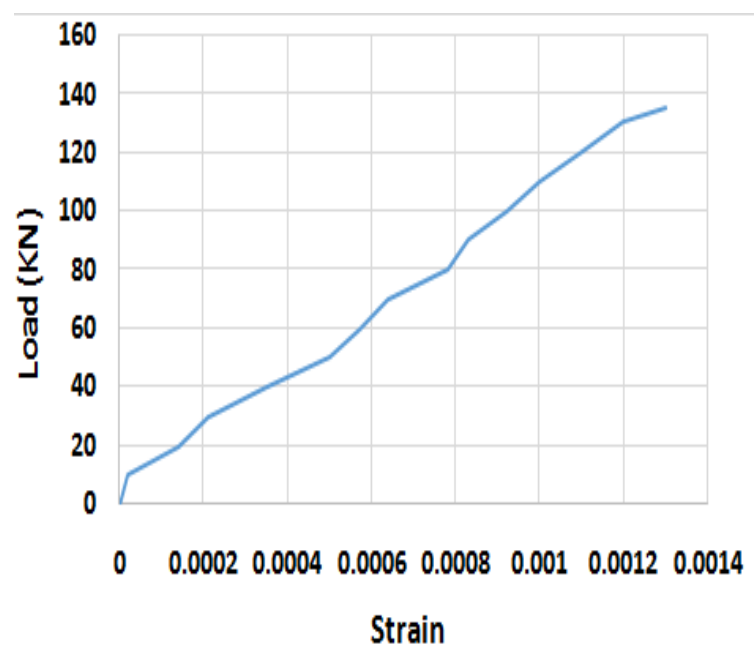

Figure 29 Load_strain of steel of B6

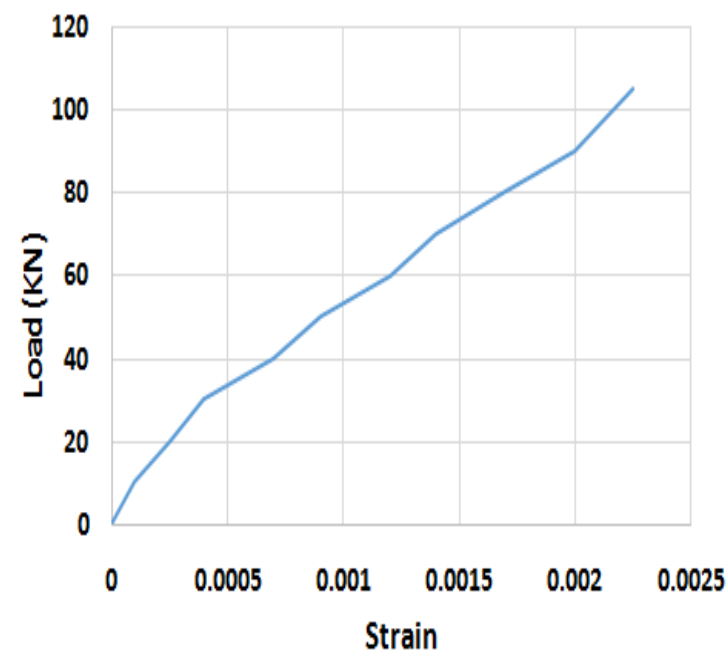

Figure 31 Load_strain of steel of B7 


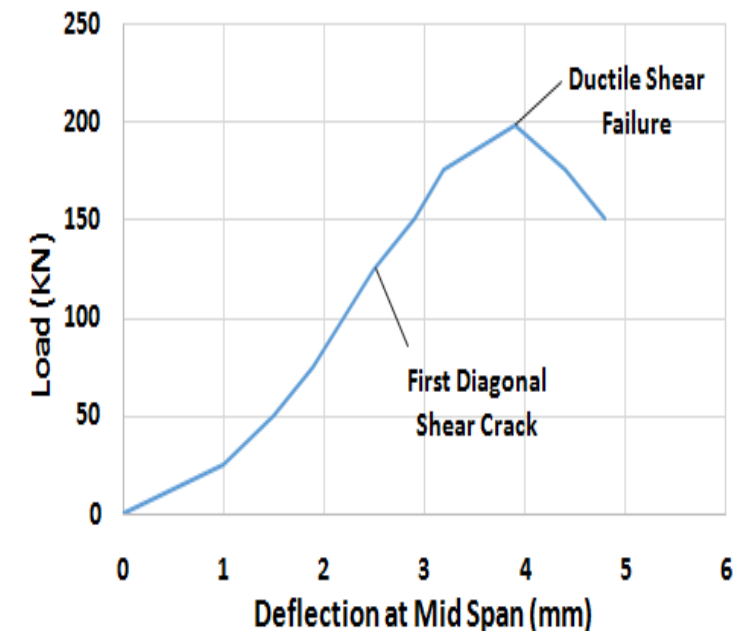

Figure 32 Load-deflection curve for beam B8

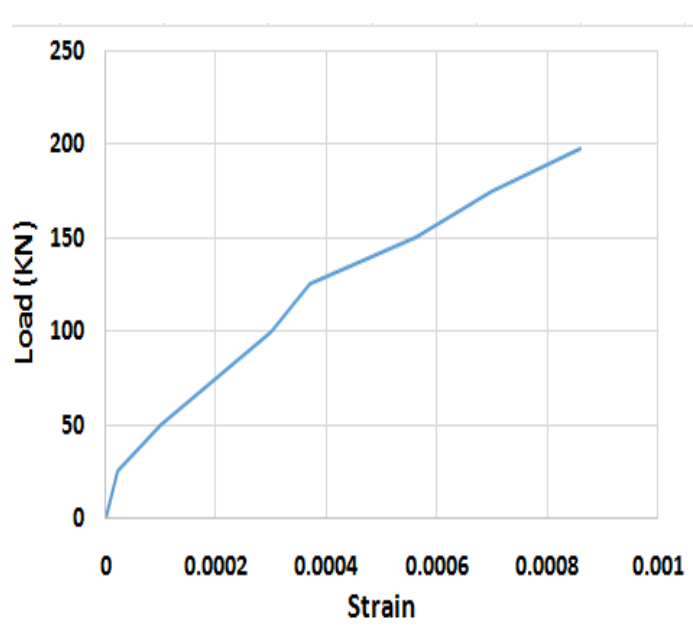

Figure 33 Load_strain of steel of B8

\section{CONCLUSION}

It was concluded that

- Compressive strength is regarded as indicator on mechanical properties, so that the splitting tensile strength of lightweight aggregate concrete is less than that for normal weight concrete lightweight aggregate concrete has lower ultimate load and less degree of ductility than normal weight concrete,

- Increasing the value of steel to concrete ratio the ultimate load of lightweight aggregate concrete also increases showing shear failure with higher degree of ductility, otherwise flexural tensile failure occurs,

- The ultimate load decreases in case of three points of loading than the four points of loading case, shear reinforcement influences flexural behavior of lightweight aggregate concrete beams slightly.

\section{REFERENCES}

[1] Niyazi Ugur Kockal, Turan Ozturan, Strength and elastic properties of structural light weight concretes. Materials \& Design, 32(4), 2011, pp. 2396-2403.

[2] Ning Liu, Bing Chen, Experimental study of the influence of EPS particle size on the mechanical properties of EPS lightweight concrete. Construction and Building Materials, 68, 2014, pp. 227-232.

[3] Ali A. Sayadi, Juan V. Tapia, Thomas R. Neitzert, G. Charles Clifton, Effects of expanded polystyrene (EPS) particles on fire resistance, thermal conductivity and compressive strength of foamed concrete. Construction and Building MaterialHYPERLINK "https://www.sciencedirect.com/science/journal/09500618"s, 112, 2016, pp. 716-724.

[4] Daneti Saradhi Babu, K. Ganesh Babu Wee Tiong-Huan, Effect of polystyrene aggregate size on strength and moisture migration characteristics of lightweight concrete. Cement and Concrete Composites, 28 (6), 2006, pp. 520-527.

[5] Yi Xu, Linhua Jiang, Jinxia Xu, Yang Li, Mechanical properties of expanded polystyrene lightweight aggregate concrete and brick. Construction and Building Materials, 27(1), 2012, pp. 32-38.

[6] Tommy Y. Lo, W.C. Tang, H.Z. Cui, The effects of aggregate properties on lightweight concrete. Building and Environment, 42(8), 2007, pp. 3025-3029. 
[7] Robert Le Roy, Edouard Parant, Claude Boulay, Taking into account the inclusions' size in lightweight concrete compressive strength prediction. Cement and Concrete Research, 35 (4), 2005, pp. 770-775.

[8] K. Miled, K. Sab, R. Le Roy, Particle size effect on EPS lightweight concrete compressive strength: Experimental investigation and modelling. Mechanics of Materials, 39(3), 2007, pp. 222-240.

[9] Chengchen Cui, Qiang Huang, Dongbin Li, Chunri Quan, Hongchao Li, Stress-strain relationship in axial compression for EPS concrete ash. Construction and Building Materials, 105, 2016, pp. 377-383.

[10] P. T. Wang, S. P. Shah, and A. E. Naaman, Stress-Strain Curves of Normal and Lightweight Concrete in Compression. Journal Proceeding, 75(11), 2016, pp. 603-611.

[11] J.M Chi, R Huang, C.C Yang, J. J Chang, Effect of aggregate properties on the strength and stiffness of lightweight concrete. Cement and Concrete Composites, 25(2), 2003, pp. 197-205.

[12] Costin Andrei Cadere, Marinela Barbuta, Bogdan Rosca, Adrian Alexandru Serbanoiu, Andrei Burlacu, and Irina Oancea, Engineering properties of concrete with polystyrene granules. Procedia Manufacturing, 22, 2018, pp. 288-293.

[13] H.Z. Cui, Tommy Yiu Lo, Shazim Ali Memon, F. Xing, X. Shi, Experimental investigation and development of analytical model for pre-peak stress-strain curve of structural lightweight aggregate concrete. Construction and Building Materials, 36, 2012, PP. 845859.

[14] ImanM.Nikbin,HYPERLINK"https://www.sciencedirect.com/science/article/pii/S016784 4217304615"Maryam Golshekan, The effect of expanded polystyrene synthetic particles on the fracture parameters, brittleness and mechanical properties of concrete. Theoretical and Applied Fracture Mechanics, 94, 2018, pp. 160-172.

[15] Eivind Hognestad, Richard C. Elstner and J. A. Hanson, Sheer Strenth of Reinforced Structural Lightweight Aggregate Concrete Slabs. Journal Proceedings, 61(6), 1964, PP. 643-656.

[16] H.Z. Cui, Tommy Yiu Lo, Shazim Ali Memon, Weiting Xu, Effect of lightweight aggregates on the mechanical properties and brittleness of lightweight aggregate concrete. Construction and Building Materials, 35, 2012, pp. 149-158.

[17] P.L.N.HYPERLINK

"https://www.sciencedirect.com/science/article/abs/pii/S0950061817302106"

HYPERLINK

"https://www.sciencedirect.com/science/article/abs/pii/S0950061817302106"Fernando, M.T.R.HYPERLINK

"https://www.sciencedirect.com/science/article/abs/pii/S0950061817302106"

HYPERLINK

"https://www.sciencedirect.com/science/article/abs/pii/S0950061817302106"Jayasinghe,

C. Jayasinghe, Structural feasibility of Expanded Polystyrene (EPS) based lightweight concrete sandwich wall panels. Construction and Building Materials, 139, 2017, pp. 45-51. 